Journal of Agricultural Science

Research Article (Araştırma Makalesi)

\title{
Determination of the Stress Responses and Mineral Compositions of Some Common Wheats (Triticum aestivum L.) under Salt Treatment
}

\author{
Hasan CAN ${ }^{*}$, Mehmet HAMURCU ${ }^{2}$, Sait GEZGIN ${ }^{3}$, Erdogan Esref HAKKI ${ }^{4}$ \\ ${ }^{1}$ Kyrgyz-Turkish Manas University Univ., Agr. Faculty, Field Crop and Horticulture Dep., Bishkek, Kyrgyzstan \\ ${ }^{2,3,4}$ Selcuk University, Agriculture Faculty, Soil Science and Plant Nutrition Department, Konya, Turkey \\ ${ }^{1}$ https://orcid.org/0000-0002-3276-0106 ${ }^{2} \mathrm{https}: / /$ orcid.org/0000-0001-7378-4406 ${ }^{3} \mathrm{https}$ ://orcid.org/0000-0002-3795-4575 \\ ${ }^{4}$ https://orcid.org/0000-0001-7147-7875 \\ *Corresponding authors e-mail: hasancan194@yahoo.com.tr
}

\section{Article Info}

Received: 30.09.2020

Accepted: 23.05 .2021

Online Published 30.06.2021

DOI: 10.29133 /yyutbd. 802653

Keywords

HKT genes,

$\mathrm{K} / \mathrm{Na}$ rate,

Proline,

Wheat,

Salt tolerance,

Salinity stress.

\begin{abstract}
The aim of this research is to evaluate and analyze the influence of different degrees of salt stress on the tolerance of Australian wheat lines having characteristics derived from wild types in comparison with a local cultivar welladapted to Anatolian conditions under controlled conditions. In the research, the two lines, namely AU5924 and AU5907, adapted to Australian conditions harbor HKT1;4 and HKT1;5 loci and Bayraktar 2000 cultivar used as genetic material. In our study, a trial plan with four replicates and two salt treatment doses (0 mM control group and $200 \mathrm{mM}$ stress group) was designed. The samples were collected for elemental analysis, measuring physiological parameters as well as determining proline content after the appearance of stress symptoms. In this respect, $(\mathrm{K})$, known to play an important role in enhancing stress tolerance, was found to be higher in $H K T$-containing lines in comparison to Bayraktar 2000. HKT genes could improve the production of Anatolian varieties. While the dry weight of the genotype Bayraktar 2000 was higher than the lines checked, the proline content of line 5907 was lower and the potassium and $(\mathrm{K} / \mathrm{Na})$ ratio decreased. These parameters effectively increased the dry weight under salt stress. However, the line 5907 demonstrated the best tolerance among all analyzed genotypes.
\end{abstract}

\section{Bazı Ekmeklik Buğdayların Tuz Uygulamasına Tepkileri ve Besin Elementi İçeriklerinin Belirlenmesi}

\section{Makale Bilgileri}

Geliş: 30.09 .2020

Kabul: 23.05.2021

Online Yayınlanma 30.06.2021

DOI: $10.29133 /$ yyutbd. 802653

Anahtar kelimeler
HKT genleri,
K/Na,
Proline,
Buğday,
Tuza tolerans,
Tuz stresi.

Öz: Bu çalışmanın amacı, yabani formların genetik özelliklerinden yararlanarak elde edilen Avustralya kökenli buğday hatları ile Anadolu'ya uyum yapan yerel buğday çeşidimizin tuz stresinden ne derece etkilendiklerini karşılaştırmalı ve kontrollü koşullarda irdelemektir. Araştırmada, Avustralya koşullarına uyum yapan ve HKT1;4 ile HKT1;5 lokuslarını taşıyan AU924 ve AU5907 hatları ile Bayraktar 2000 çeşidi kullanılmıştır. Deneme; kontrol $(0 \mathrm{mM})$ ve stres koşullarında $(200 \mathrm{mM})$ iki doz ve 4 tekrarlamalı olarak düzenlenmiş; stres etkisindeyken prolin ve element analizi için örneklenme ile temel bazı fizyolojik büyüme parametrelerinin saptanmasına yönelik gözlemlerin yapılmıştır. Buna göre, parametreler ile kritik bazı makro ve mikro besin elementleri açısından genotiplerin tuz stresinden olumsuz etkilendikleri saptanmış, strese toleransın artışında pay sahibi olan (K) içeriğinin, toleranslı olduğu bilinen Nax taşıyıcısı yabancı buğday hatlarında yerel çeşide göre daha yüksek olduğunun anlaşılması ve bu bakımdan etkili genlerin Anadolu kökenli buğday çeşitlerine 
aktarılmasının tuzlu ortamlarda buğday üretimimizin arttırılmasına katkı sağlayabileceği sonucuna varılmış; kuru ağırlık açısından en iyi genotipin Bayraktar 2000 olduğu saptanmış, AU5907'deki prolin içeriğinin diğerlerinden daha düşük ve $(\mathrm{K})$ ile $(\mathrm{K} / \mathrm{Na})$ oranlarındaki azalma, tuz stresinde artış göstererek, AU5907'deki tuza tolerans diğerlerine göre ön plana çıkmıştır.

\section{Introduction}

The demand for cereals has been growing tremendously worldwide and the most cultivated and important one is common wheat (Triticum aestivum), in other words, the common wheat is the most consumed cereal globally (Wang et al., 2020). Together with other major cereals (Zea mays, Oryza sativa), T. aestivum is the most vulnerable to stress (Zörb et al., 2019). The extremely harsh environmental conditions such as drought, salinity, heavy metal, etc. could severely reduce wheat production. For example, drought and salinity stress, especially in arid and semi-arid regions affect the wheat production severely. Both these stress conditions have become major concerns of the modern world and therefore getting increasing attention. Salinization, especially in cultivated (approximate $20 \%$ of cultivated and $33 \%$ of irrigated land) areas is a major yield-limiting factor (Cirillo et al., 2018). As the vital necessities (such as nutrient, water, light, etc.) of plants during the growing stage are not met properly, the majority of plant yield including that of wheat is reduced in the cultivation area (Zörb et al., 2019). The salinity impairs more than one of these basic factors by manipulating the plants in two ways: first, ion toxicity that impairs photosynthesis and second is excess of $(\mathrm{Na})$ that inhibits protein synthesis (Isayenkov and Maathuis, 2019).

The dominant reason for the emergence of salinization-based soil pollution is the heavily used irrigation system in agricultural production for providing food supply. A larger area of irrigated lands has been severely affected by the increased salinity in the soil ecosystem (Singh, 2010; Valipour, 2014). To be considered a soil type as salty, it must contain at least $4 \mathrm{dS} \mathrm{m}^{-1} \mathrm{EC}$ values in which equal to the $40 \mathrm{mmol} \mathrm{L}^{-1} \mathrm{NaCl}$ or $0.2 \mathrm{MPa}$ osmotic pressure together with 7.0 to $8.5 \mathrm{pH}$ value (Ghosh et al., 2016).

Considering these challenges, the development of new tolerant varieties is required to provide food supply to the growing world populations. In this respect, wild types are an indispensable source for the development of tolerant varieties. To cope with salinity stress, some other salt-tolerant loci have been discovered and transferred to the modern wheat varieties from their wild relatives such as einkorn wheat (Triticum monococcum) and entitled to Naxl and Nax2 loci (James et al., 2006).

The main aim of the present study was to determine the changes in the mineral nutrition profile of some wheat genotypes under salinity stress conditions and observe physiological responses of selected wheat genotypes at an early stage. The Nax locus introgressed lines were obtained from Australia; these lines can be easily screened for the Nax locus using specific molecular markers. However, a preliminary study including the comparisons between the cultivar well adapted to the Central Anatolian conditions and provided lines should be realized and their activities should be checked under saline conditions.

\section{Material and Methods}

\subsection{Experimental materials}

AU5924 and AU5907 common wheat (T. aestivum L.) lines (kindly provided by CSIRO) that are carriers of HKT1;4 (Nax2), and HKT1;5 (Naxl) salinity tolerance loci and the Bayraktar 2000 wheat (T. aestivum L.), a registered variety, which is frequently cultivated under the Central Anatolian conditions, were used to investigate stress responses and mineral nutrient contents under the salinity stress conditions. Major differences of selected genetic materials are summarized as follows: the AU5924 and AU5907 lines were derived by introducing T. monococccum originated HKT loci, whereas the Bayraktar 2000 has the salinity stress tolerant loci. 


\subsection{Experimental details}

The seeds were sterilized using sodium hypochlorite containing Tween 20 and subsequently in $75 \%$ ethanol for 5 min (Hamurcu et al., 2015). The experiment was performed according to a randomized plot design in a hydroponic chamber with four replications. For salinity stress treatment, based on our preliminary results, $200 \mathrm{mM}$ salt concentration was used as the salinity stress, whereas Hoagland solution prepared without any salt addition was used as the control group. Germinated seeds were transferred and grown under the following conditions; $45 \%$ to $55 \%$ humidity, $16 / 8 \mathrm{~h} \mathrm{light} / \mathrm{dark}$ photoperiod, a temperature of $21 \pm 1^{\circ} \mathrm{C}$, and 10000 Lux/daylight intensity (Hamurcu et al., 2015). For the salt application, the plants were allowed to reach the first three-leaved stage after which salt treatments were applied in each pot of stress group solution, whereas the control group continued to grow without salt addition (harvested at the end of 3 weeks).

\subsection{Plant growth measurements}

Before harvesting, roots and stems of control and salt-treated plant samples were separated from each other. Root and stem lengths and root and stem fresh weights of each group were measured (Munns and James, 2003).

\subsection{Elemental analysis}

The plant samples were dried at $70{ }^{\circ} \mathrm{C}$ until their weight became constant. Afterward, all samples were fine powdered separately using a grinder. Plant samples were mineralized (CEM Mars 5) by heating at $210{ }^{\circ} \mathrm{C}$ in a microwave oven and using a high-pressure step (200 PSI). After cooling, the mineralized samples were leached from 1 to $2 \mu \mathrm{m}$ filter paper (Whatman no: 42) and filled up to $15 \mathrm{~mL}$ with ultrapure water in falcon tubes (Hakki et al., 2014). Standard solutions were prepared, and calibration of inductively coupled plasma optical emission spectroscopy was performed using multielement stock solutions of 1000 ppm (Merck). The concentrations of (B), (Ca), (Cu), (Fe), (K), (Mg), $(\mathrm{Na})$, and $(\mathrm{Zn})$ were determined using the ICP-AES (Inductively coupled plasma atomic emission spectroscopy) apparatus.

\subsection{Proline analysis}

The method introduced by Bates et al. (1973) was used to determine the proline content. The absorbance value of the toluene fraction aspirated from the liquid phase was read at $520 \mathrm{~nm}$ in the spectrophotometer. The proline concentration in the analyzed samples was calculated using the calibration curve and expressed as $\mu$ mol proline $\mathrm{g}^{-1}$ fresh weight.

\subsection{Statistical analysis}

The observations and measurements were first subjected to variance analysis according to the randomized blocks factorial experiment pattern using MSTAT-C statistical software package program. LSD analysis was done to the mean of traits that were found to be at least $5 \%$ significant among the analyzed traits. A correlation test was performed using MSTAT-C statistical software.

\section{Results}

\subsection{Plant growth responses of wheat genotypes under salt-stress}

The seedlings of wheat grown under salinity stress in the hydroponic chamber displayed a significant reduction in root and leaf length, and root and leaf fresh and dry weights. Plant growth responses of wheat genotypes under salt stress are shown in Figures 1-3. While the maximum plant height was observed in the Bayraktar 2000 under control condition in comparison with the remaining lines, it also exhibited the highest percentage decrease (20\%) under salt stress (Figure 1A). The percentage reduction in plant heights in the lines AU5907 and AU5AU924 was found to be $10 \%$ and 
$8 \%$, respectively. In the case of root lengths, the maximum percentage reduction was detected in the line AU5924 (29\%) and root length in the line AU5907 showed a 22\% decrease, whereas the decrease in the root length of Bayraktar 2000 was $19 \%$ in comparison to the control groups of same genotypes (Figure 1B).

As shown in Figure 2B, the reduction in the plant dry weight of wheat seedlings varied from $26 \%$ to $28 \%$. As an exception to the pattern of reduction in the dry matter content, the fresh and dry weight results in the line AU5907 were found to be the same under both conditions (Control and Salinity stress). Regarding the root fresh weights of wheat seedlings, the reduction rates in root fresh weight of genotypes included in the presented study were - the Bayraktar $2000(38 \%)$, the line AU5924 (27\%), and the line AU5907 (25\%) (Figure 3A). However, root dry weight results appeared to be significantly different from the fresh weight results (Figure $3 \mathrm{~B}$ ).

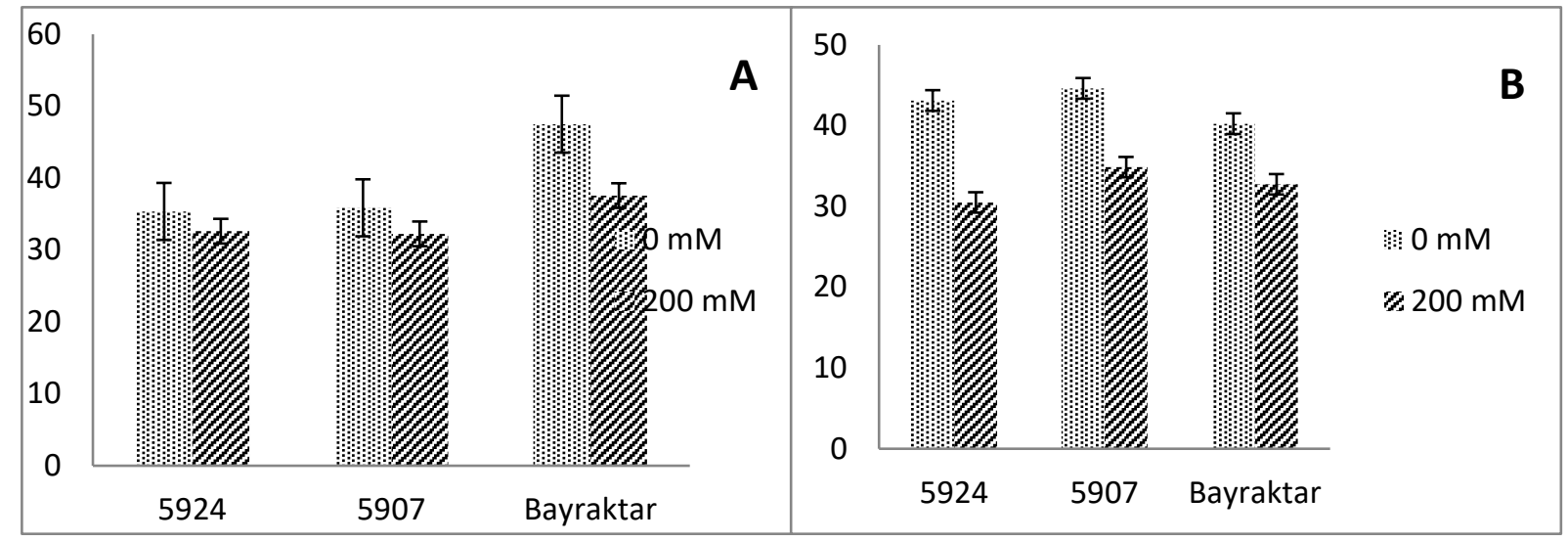

Figure 1. Plant and root length of evaluated wheat genotypes under salinity stress and normal conditions (A: Plant length (cm), B: Root length $(\mathrm{cm})$ ).

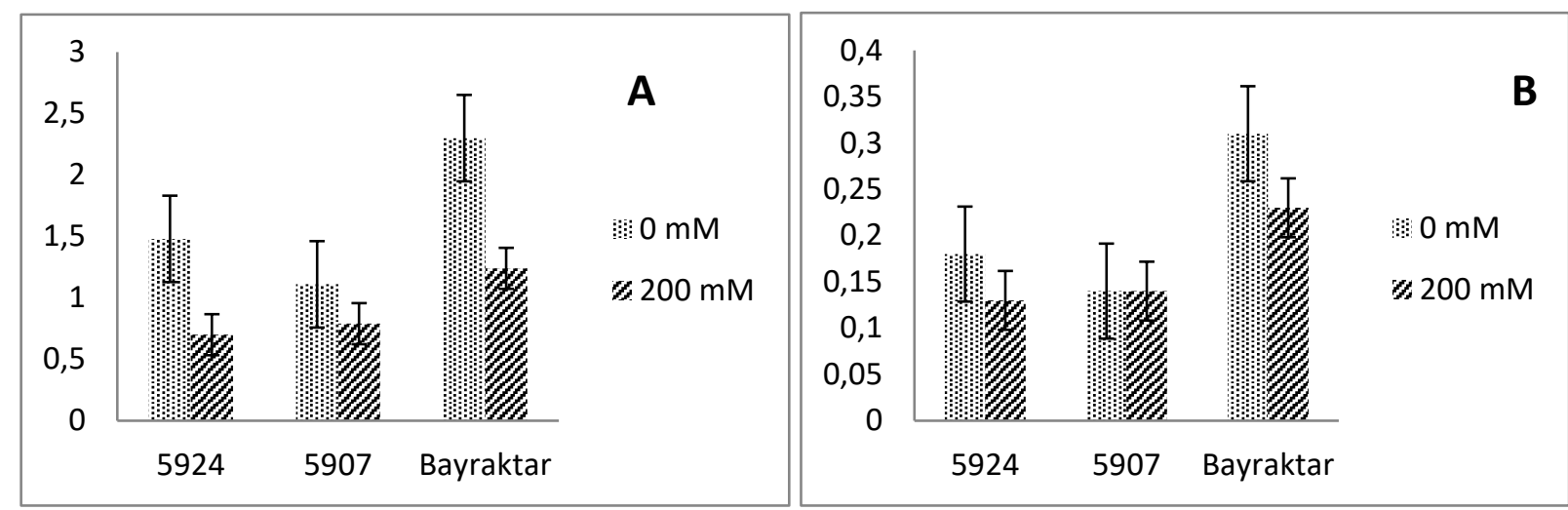

Figure 2. Plant fresh and dry weight of evaluated wheat genotypes under salinity stress and normal conditions (A: Plant fresh weight (g), B: Plant dry weight (g)).

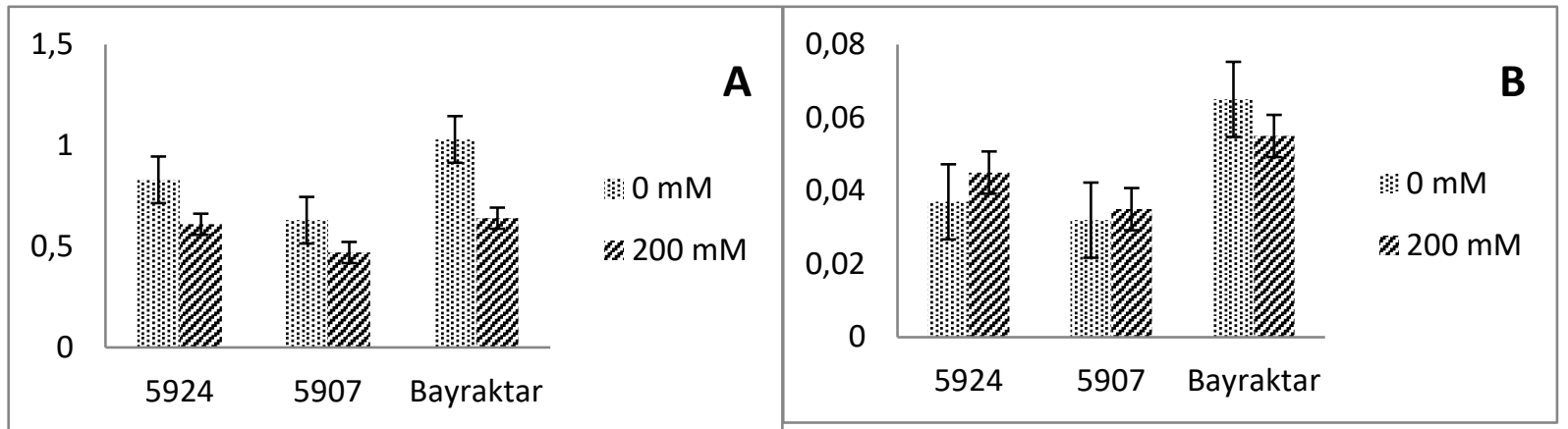

Figure 3. Root fresh and dry weight of evaluated wheat genotypes under salinity stress and normal conditions (A: Root fresh weight (g), B: Root dry weight (g)). 


\subsection{Mineral nutrients of wheat seedlings against salt-stress}

After determining the concentrations of macro-and microelements in the analyzed wheat seedlings samples, a literature survey related to these elements in plant metabolism was conducted to identify the permissible limits. These limits varied from $0.2 \%$ to $1.0 \%$ for $(\mathrm{Ca}), 1 \%$ to $5 \%$ for $(\mathrm{K})$, $0.1 \%$ to $0.4 \%$ for $(\mathrm{Mg}), 10$ to $200 \mathrm{mg} \mathrm{kg}{ }^{-1}$ for (B), 5 to $30 \mathrm{mg} \mathrm{kg}^{-1}$ for $(\mathrm{Cu}), 100$ to $500 \mathrm{mg} \mathrm{kg}^{-1}$ for (Fe), and 25 to $150 \mathrm{mg} \mathrm{kg}-1$ for (Zn) (Maathuis, 2009; Rattan, 2015).

The ICP-AES (Inductively coupled plasma atomic emission spectroscopy) data revealed a substantial difference in the concentration of minerals in wheat seedlings under salinity stress. The root and shoot macro-and micronutrient contents of wheat seedlings are summarized in Tables $1-2$. In the case of $(\mathrm{Ca})$, the concentration of root and shoot decreased (percentage) by approximately half in comparison with that under salinity stress (Table 1$)$. $(\mathrm{Mg})$ concentration in the roots and shoots of wheat seedlings ranged from $0.177 \%$ to $0.279 \%$ in shoots (control), $0.159 \%$ to $0.198 \%$ in shoots (stress), $0.144 \%$ to $0.211 \%$ in roots (control), and $0.018 \%$ to $0.025 \%$ in roots (stress) (Tables $1-2$ ). The (Na) content of included wheat genotypes substantially varied in control and salt applied groups as follows: $0.078 \%$ to $0.176 \%$ within control shoots, $2.1 \%$ to $2.7 \%$ within stressed shoots, $0.543 \%$ to $1012 \%$ within control roots, and $2.2 \%$ to $3.3 \%$ within stressed roots (Tables $1-2)$. As in (Mg), salinity significantly influenced the $(\mathrm{K})$ content of roots and shoots of seedlings as compared with the control groups, ranging from $3.8 \%$ to $4.6 \%$ in the control group of shoot samples, from $3.1 \%$ to $3.8 \%$ in stressed shoot samples, from 4.9 to $5.6 \%$ in the control root samples, and from $1 \%$ to $1.4 \%$ in stressed root samples (Tables 1-2).

Table 1. Shoot macro (\%) and micronutrient $\left(\mathrm{mg} \mathrm{kg}^{-1}\right)$ concentrations of wheat under salinity stress condition and control

\begin{tabular}{|c|c|c|c|c|c|c|c|c|}
\hline \multirow[t]{2}{*}{$(\%)$} & \multicolumn{2}{|c|}{$(\mathrm{Ca})$} & \multicolumn{2}{|c|}{$(\mathrm{Mg})$} & \multicolumn{2}{|c|}{$(\mathrm{Na})$} & \multicolumn{2}{|c|}{$(\mathrm{K})$} \\
\hline & Control & Stress & Control & Stress & Control & Stress & Control & Stress \\
\hline AU5924 & 0.513 & 0.304 & 0.253 & 0.198 & 0.112 & 2.709 & 4.330 & 3.777 \\
\hline AU5907 & 0.604 & 0.285 & 0.279 & 0.196 & 0.176 & 2.553 & 4.624 & 3.800 \\
\hline Bayraktar 2000 & 0.546 & 0.371 & 0.177 & 0.159 & 0.078 & 2.180 & 3.840 & 3.178 \\
\hline \multirow{2}{*}{$\left(\mathrm{mg} \mathrm{kg}^{-1}\right)$} & \multicolumn{2}{|c|}{ (B) } & \multicolumn{2}{|c|}{$(\mathrm{Cu})$} & \multicolumn{2}{|c|}{$(\mathrm{Fe})$} & \multicolumn{2}{|c|}{$(\mathrm{Zn})$} \\
\hline & Control & Stress & Control & Stress & Control & Stress & Control & Stress \\
\hline AU5924 & 9.0 & 7.3 & 11.7 & 7.0 & 112.4 & 47.3 & 67.3 & 33.3 \\
\hline AU5907 & 11.2 & 6.1 & 11.4 & 6.7 & 74.4 & 51.0 & 68.8 & 33.2 \\
\hline Bayraktar 2000 & 7.8 & 5.2 & 9.1 & 5.9 & 67.6 & 67.08 & 57.8 & 45.3 \\
\hline
\end{tabular}

Concerning micronutrients, the (B) contents of the shoot of wheat seedlings were found to be significantly different, ranging from 7.8 to $11.2 \mathrm{mg} \mathrm{kg}^{-1}$ in the control group and from 5.2 to $7.3 \mathrm{mg}$ $\mathrm{kg}^{-1}$ under salinity stress (Table 1). In root samples, (B) contents fluctuated between 2.47 and $3.51 \mathrm{mg}$ $\mathrm{kg}^{-1}$ in the control group and between 0.44 and $1.06 \mathrm{mg} \mathrm{kg}^{-1}$ under salinity stress (Table 2). $(\mathrm{Cu})$ concentrations of wheat seedlings were found to range from 9.1 to $11.7 \mathrm{mg} \mathrm{kg}^{-1}$ and from 5.9 to 7.0 $\mathrm{mg} \mathrm{kg}{ }^{-1}$ in control and stressed conditions, respectively, in shoot dry weights (Table 1). The (Fe) concentrations were: 67.6 to $112.4 \mathrm{mg} \mathrm{kg}^{-1}$ in shoot control and 47.3 to $67.08 \mathrm{mg} \mathrm{kg}^{-1}$ in shoot stress (Table 1). The (Fe) concentrations of root samples were detected to range from 494.4 to $963.7 \mathrm{mg} \mathrm{kg}^{-1}$ in control and 995.6 to $1122.7 \mathrm{mg} \mathrm{kg}^{-1}$ under stress (Table 2). Finally, the ( $\mathrm{Zn}$ ) levels in the analyzed wheat seedlings were: 57.8 to $67.3 \mathrm{mg} \mathrm{kg}^{-1}$ in the control shoot and 33.2 to $45.3 \mathrm{mg} \mathrm{kg}^{-1}$ in the stressed shoot (Table 1), whereas it ranged from 106.5 to $289.4 \mathrm{mg} \mathrm{kg}^{-1}$ in control root and from 31.7 to $58.4 \mathrm{mg} \mathrm{kg}^{-1}$ in stressed root samples (Table 2). 
Table 2. Root macro (\%) and micronutrient $\left(\mathrm{mg} \mathrm{kg}^{-1}\right)$ concentrations of wheat under salinity stress condition and control

\begin{tabular}{|c|c|c|c|c|c|c|c|c|}
\hline \multirow[t]{2}{*}{$(\%)$} & \multicolumn{2}{|c|}{$(\mathrm{Ca})$} & \multicolumn{2}{|c|}{$(\mathrm{Mg})$} & \multicolumn{2}{|c|}{$(\mathrm{Na})$} & \multicolumn{2}{|c|}{$(\mathrm{K})$} \\
\hline & Control & Stress & Control & Stress & Control & Stress & Control & Stress \\
\hline AU5924 & 0.212 & 0.145 & 0.211 & 0.021 & 0.986 & 3.156 & 5.618 & 1.467 \\
\hline AU5907 & 0.270 & 0.137 & 0.174 & 0.018 & 1.012 & 3.307 & 5.620 & 1.079 \\
\hline Bayraktar 2000 & 0.218 & 0.082 & 0.144 & 0.025 & 0.543 & 2.265 & 4.910 & 1.103 \\
\hline$\left(\mathrm{mg} \mathrm{kg}^{-1}\right)$ & \multicolumn{2}{|c|}{ (B) } & \multicolumn{2}{|c|}{$(\mathrm{Cu})$} & \multicolumn{2}{|c|}{$(\mathrm{Fe})$} & \multicolumn{2}{|c|}{$(\mathrm{Zn})$} \\
\hline & Control & Stress & Control & Stress & Control & Stress & Control & Stress \\
\hline AU5924 & 2.97 & 0.44 & 111.6 & 36.8 & 583.2 & 1002.8 & 190.3 & 58.4 \\
\hline AU5907 & 3.51 & 1.06 & 98.3 & 34.6 & 963.7 & 995.6 & 289.4 & 51.0 \\
\hline Bayraktar 2000 & 2.47 & 0.93 & 61.0 & 30.4 & 494.4 & 1122.7 & 106.5 & 31.7 \\
\hline
\end{tabular}

\subsection{Proline contents of wheat seedlings against salt-stress}

The changes in the proline contents related to the wheat seedlings are summarized in Table 3. These results showed that the application of salt stress increased the proline content by approximately 10-fold in the root samples collected from the line AU5924 and Bayraktar 2000 genotypes. In the line AU5907, this increase was limited to only 4.75 fold as compared to the control group (fold changes calculated from Table 3).

Table 3. Proline concentrations of wheat root and shoot samples under salinity stress condition and control ( $\mu \mathrm{mol} \mathrm{g}^{-1}$ Fresh Weight)

\begin{tabular}{lcccc}
\hline & \multicolumn{2}{c}{ Roots } & \multicolumn{2}{c}{ Shoot } \\
\hline & Control & $200 \mathrm{mM}$ stress & Control & $200 \mathrm{mM}$ stress \\
\cline { 2 - 5 } AU5924 & 0.03 & 0.32 & 0.03 & 2.26 \\
AU5907 & 0.04 & 0.19 & 0.04 & 0.84 \\
Bayraktar 2000 & 0.03 & 0.31 & 0.05 & 1.55 \\
\hline
\end{tabular}

Compared to root samples, the proline contents of wheat shoot samples differed. The highest increase was observed in the line AU5924 leaves with 75 fold more than compared to the control shoot samples. The next highest increase was observed in the Bayraktar 2000 leaves with approximately 31 -fold more increased value as compared to the control leaf sample. Finally, the lowest amount of proline increase occurred in the line the AU5907 shoots with a 21-fold increase, as compared to control samples (fold changes calculated from Table 3).

\section{Discussion}

In the present study, salinity stress led to an ion imbalance in the composition of macro and micronutrients of wheat seedlings. Salinity also reduced adversely the physiological growth in early wheat seedlings. Several studies have reported a decrease in physiological parameters under salt stress including, cereal crop species. For example, $H v H K T 1,5$ gene containing Hordeum vulgare haplotypes (group B) and sensitive genotypes were compared in terms of salt stress $(200 \mathrm{mM} \mathrm{NaCl})$ induced decrease in plant and shoot dry weight (van Bezouw et al. 2019). Another similarity between the study of Van Bezouw et al. (2019) and the given is that it did not cause any decrease in the root dry weight in the line AU5907 and the HvHKT gene containing Hordeum vulgare genotypes. However, significant differences were observed in the shoot $\left(\mathrm{Na}^{+}\right),\left(\mathrm{K}^{+}\right),\left(\mathrm{Na}^{+} / \mathrm{K}^{+}\right)$contents within the salt treatment and control groups of Hordeum vulgare. Khan et al. (2019) reported reduced root length, root and shoot fresh weights, and shoot and root dry weights in some common wheat seedlings under salt stress. Several other studies have tried to find the resistance level of selected genotypes against salinity stress and have reported reduced physiological growth as a response to salt stress. These include studies conducted in boron and salinity treatment in common wheat (Naz et al., 2018), silicon treatment responses against salinity stress in common wheat (Sienkiewicz-Cholewa et al., 2018), and physiologic and mineral nutrition responses of Gossypium hirsutum genotypes to salt stress. 
Munns and James (2003) stated that root and leaf elongation rates are the key parameters of early (two-week-old seedlings under controlled conditions) detection of salinity tolerance in cereals, particularly wheat, besides the biomass and yield parameters. From the perspective of growth parameters, the order of decreasing plant heights (decreasing rate stated as percentages) was observed to be Bayraktar $2000>$ AU5907 > AU5924, whereas the order of decreasing root lengths (decreasing rate stated as \%) was found to be AU5924 > AU5907 > Bayraktar 2000. The osmotic imbalance (water deficit plant tissue) within the stressed plants (Munns and James, 2003; van Bezouw et al., 2019) owing to impaired water absorption resulted in fluctuating fresh weights of wheat seedlings under normal and stress conditions. The number, growth, and size of levels depend on several factors such as phyllochron, plastochron, polarity, blade size, leaf orientation and angle, and genetics (Shaaf et al., 2019). These factors affect the above-ground biomass production of plants and are controlled by the stability of the genetic structure (cultivar and breeding line differences). Fresh weights of wheat seedlings may be insufficient to explain the difference between the genotypes with salt resistance. However, it provides general anticipation related to the resistance status of evaluated genotypes. As seen in Table 4, the best recovering rate in terms of plant fresh weight contents under salt stress was observed in the line AU5907. This line also exhibited the best performance against $200 \mathrm{mM}$ salinity stress in terms of dry matter, concerning both roots dry and shoot dry weight contents. Munns et al. (2012) tested the Tamaroi lines introgressed with TmHKT1;5-A and reported the yield increase under salinity stress under field conditions. Similar supportive studies were conducted in wheat and close relative species were published; these were related to the superior performance of $H K T$ gene introgressed lines under both field and in vitro conditions (Rahnama et al., 2011; James et al., 2012; Kobayashi et al. 2017; Tounsi et al., 2017). Similar to our study, these studies, clearly demonstrated that the lines expressing the $H K T$ genes performed better than those not expressing these genes under salt stress conditions under both fields and in vitro conditions.

Based on the calculations given in Table 1, the calculated rates of $(\mathrm{Na})$ entrance in the shoot are in the order of the Bayraktar $2000>$ the line AU5924 > the line AU5907. This implies that 27.9 fold more (Na) is taken into the shoots in the Bayraktar 2000 in comparison to the control samples, whereas 14.5 fold more $(\mathrm{Na})$ is transferred to the shoots in the line 5907 in comparison to the control samples. James et al. (2006) reported that both Naxl and Nax2 introgressed lines can restrict (Na) uploading from roots to shoots. In addition to this restriction function, Naxl also has the capability of retrieving the previously unloaded $(\mathrm{Na})$ from the xylem tissue in durum wheat (James et al., 2006). The (Na) unloading from plant shoots stated by James et al. (2006) has been observed in the line Naxl introgressed 5907 under salinity stress conditions. These results are also supported by other studies, such as common wheat under salinity and waterlog conditions (James et al., 2011) and durum wheat under saline soil conditions (James et al., 2012).

Table 4. Salinity tolerance of hexaploid wheat cultivars and selections grown in control or salt treatment $(200 \mathrm{mM} \mathrm{NaCl})$ after $15 \mathrm{~d}$

\begin{tabular}{lccc}
\hline \multirow{2}{*}{ Genotypes } & \multicolumn{2}{c}{ Shoot dry weight $(\mathrm{g})$} & \multirow{2}{*}{ Salt tolerance (\%) control } \\
\cline { 2 - 4 } & Control & Salt Treatment & 72.6 \\
\hline AU5924 & 0.18 & 0.13 & 96.6 \\
AU5907 & 0.14 & 0.14 & 73 \\
Bayraktar 2000 & 0.31 & 0.23 & \\
\hline
\end{tabular}

Maintaining this strict $\left(\mathrm{K}^{+} / \mathrm{Na}^{+}\right)$balance at the cellular level during stress conditions is a major sign of tolerance against salinity as these ions play several physiological roles and $\mathrm{K}$-dependent signal pathways (Isayenkov and Maathuis, 2019). Considering the (K) contents of wheat seedlings under salinity stress conditions, the highest decrease rate was observed in the line $5907(0.824 \%)$, whereas the lowest decrease rate was observed in the line AU5924 (0.523\%). The (K) capacity of Bayraktar 2000 unstressed plants was equivalent to that of the line AU5907 within the stressed plants. This implies that when we combine this situation with the absorption of less $(\mathrm{Na})$ than others, it is observed that the best performing the genotype is line AU5907 under salt stress. That could be a possible explanation for the results shown in Tables 4-5. Table 4 shows the recovery rates of wheat seedlings under stress conditions and Table 5 provides $\left(\mathrm{K}^{+} / \mathrm{Na}^{+}\right)$under the same stress conditions. The $\left(\mathrm{K}^{+} / \mathrm{Na}^{+}\right)$ 
of line 5907 (1.48) in the given study validated with those of another study that demonstrated similar results during the salt stress-resistant genotype detection research (El-Hendawy et al., 2017). Tables 4-5 show that the line 5907 retained better recovery and $\left(\mathrm{K}^{+} / \mathrm{Na}^{+}\right)$than other compared genotypes.

Table 5. $\left(\mathrm{Na}^{+}\right)$and $\left(\mathrm{K}^{+}\right)$content in leaves of salt-treated wheat seedlings

\begin{tabular}{lccc}
\hline Genotypes & $(\mathrm{Na})$ & $(\mathrm{K})$ & $\left(\mathrm{K}^{+} / \mathrm{Na}^{+}\right)$ \\
\hline 5AU924 & 2.709 & 3.777 & 1.39 \\
5907 & 2.553 & 3.800 & 1.48 \\
Bayraktar 2000 & 2.180 & 3.178 & 1.45 \\
\hline
\end{tabular}

The root and shoot proline values of wheat seedlings in the present study are summarized in Table 5. The proline contents preferably get accumulated at a considerably higher level in leaves rather than in roots to prevent photosynthetic activity and the turgid status of the cell under salinity stress (Silva-Ortega et al., 2008). Although the given results support this finding, the proline content in salt-resistance line 5907 appeared to be lower than in other compared genotypes. Several studies have reported the proline content of resistant genotypes under salt stress to be higher than that of sensitive genotypes (Dugasa et al., 2019; Ami et al., 2020). However, the proline level of resistant line 5907 did not exactly match with the explained situation. The low level of proline in the bestperforming wheat (line 5907) could be attributed to the restricted transport of (Na) to shoots $(13.4 \%$ less (Na) transport to shoots).

In general, stress conditions triggered the accumulation of proline and related low molecular type metabolites; however, certain other inconsistent correlation results have also been published in different plants (Bhaskara et al., 2012). For example, Kim et al. (2016) observed that another member of the Poaceae family, switchgrass (salt-tolerant ones among 46 Panicum virgatum lines), behaved as the line 5907 with a slight increase in the proline content under saline condition. A possible explanation could be that the down-regulation of $P D H$ genes under the saline conditions strongly correlated with an extraordinary bidirectional balance with P5CS genes. Per et al. (2017) stated that the proline accumulation was related to the $P D H$ gene rather than the $P 5 C S$ gene, this slight increase is explained as mentioned above.

The correlation analysis was performed for shoot dry mass in the common wheat seedlings and the related parameters and results are presented in Table 6 , which show a positive or negative relation between such parameters and dry mass. A strong correlation was found between the wheat shoot dry mass and the absorption rates of cations such as $(\mathrm{Ca}),(\mathrm{Mg})$, and $(\mathrm{K})$ at a miliequivalent scale under salt stress. A moderate correlation was found between the $(\mathrm{Ca} / \mathrm{Na}),(\mathrm{Mg} / \mathrm{Na})$, and $(\mathrm{K} / \mathrm{Na})$ in the shoots of wheat seedlings under salt stress. The correlation analysis was also performed for the root dry mass of wheat seedlings and the related parameters are summarized in Table 7. Regarding shoots, a similarly strong correlation was found between the dry weight of the roots and the absorption of cations such as $(\mathrm{K}),(\mathrm{Ca})$, and $(\mathrm{Mg})$ at the miliequivalent scale. The same moderate level of correlations was also detected in root dry matter of the wheat seedlings and $(\mathrm{Ca} / \mathrm{Na}),(\mathrm{Mg} / \mathrm{Na}),(\mathrm{K} / \mathrm{Na})$ at a 0.05 significance level. When the $\mathrm{Mg}$ contents for wheat seedlings were evaluated from this angle, the correlation between the root dry mass and $\mathrm{mg}$ contents at the miliequivalent scale appeared to be more significant. Moreover, the $(\mathrm{Mg} / \mathrm{Na})$ in the shoots of wheat seedlings seemed to be important for the continuity of photosynthesis. When the $(\mathrm{Ca})$ values in the shoots of wheat seedlings were evaluated in this respect, the strong correlation of shoot dry mass and $(\mathrm{Ca})$ as miliequivalent (particularly Nax introgressed lines) was found to be a possible explanation of better performance under saline conditions. 
Table 6. Shoot dry mass (SDM), elemental concentrations $(\%)$ and miliequivalent $(\mathrm{me})$ correlations $(\mathrm{p}<0.01$ and $\mathrm{p}<0.05)$

\begin{tabular}{|c|c|c|c|c|c|c|c|c|c|c|c|c|}
\hline & SDM & $(\mathrm{Ca} \%)$ & $(\mathrm{Mg} \%)$ & $(\mathrm{Na} \%)$ & $(\mathrm{K} \%)$ & $(\mathrm{Ca} / \mathrm{Na})$ & $(\mathrm{Mg} / \mathrm{Na})$ & $(\mathrm{K} / \mathrm{Na})$ & (Proline) & $(\mathrm{Ca} \#)$ & $(\mathrm{Mg} \#)$ & $(\mathrm{K} \#)$ \\
\hline$(\mathrm{Ca} \%)$ & 0.371 & & & & & & & & & & & \\
\hline$(\mathrm{Mg} \%)$ & -0.300 & $0.716^{* * *}$ & & & & & & & & & & \\
\hline$(\mathrm{Na} \%)$ & $-0.461^{*}$ & $-0.933^{* *}$ & $-0.615^{* *}$ & & & & & & & & & \\
\hline$(\mathrm{K} \%)$ & -0.315 & $0.653^{* *}$ & $0.955^{* *}$ & $-0.596^{* *}$ & & & & & & & & \\
\hline$(\mathrm{Ca} / \mathrm{Na})$ & $0.649 * *$ & $0.833^{* *}$ & 0.401 & $-0.914^{* *}$ & $0.423^{*}$ & & & & & & & \\
\hline$(\mathrm{Mg} / \mathrm{Na})$ & $0.516^{* *}$ & $0.864^{* *}$ & $0.547^{* *}$ & $-0.952^{* *}$ & $0.561^{* *}$ & $0.976^{* *}$ & & & & & & \\
\hline (K/Na) & $0.571^{* *}$ & $0.835 * *$ & $0.473^{*}$ & $-0.933^{* *}$ & $0.500^{*}$ & $0.989 * *$ & $0.994 * *$ & & & & & \\
\hline (Proline) & -0.351 & $-0.811^{* *}$ & $-0.606^{* *}$ & $0.885^{* *}$ & $-0.622 * *$ & $-0.808^{* *}$ & $-0.848^{* *}$ & $-0.828^{* *}$ & & & & \\
\hline (Came) & $0.903^{* *}$ & $0.705^{* *}$ & 0.082 & $-0.732^{* *}$ & 0.063 & $0.868^{* *}$ & $0.771^{* *}$ & $0.803^{* *}$ & $-0.613^{* *}$ & & & \\
\hline (Mgme) & $0.894 * *$ & $0.709^{* *}$ & 0.145 & $-0.751^{* *}$ & 0.111 & $0.862 * *$ & $0.789 * *$ & $0.811^{* *}$ & $-0.647^{* *}$ & $0.982^{* *}$ & & \\
\hline (Kme) & $0.958^{* *}$ & $0.578^{* *}$ & -0.038 & $-0.653^{* *}$ & -0.037 & $0.813^{* *}$ & $0.712 * *$ & $0.752^{* *}$ & $-0.553 * *$ & $0.974^{* *}$ & $0.977 * *$ & \\
\hline (Name) & -0.220 & $-0.873^{* *}$ & $-0.711^{* *}$ & $-0.901^{* * *}$ & $-0.705^{* *}$ & $-0.863^{* *}$ & $-0.907^{* *}$ & $-0.886^{* *}$ & $0.834 * *$ & $-0.583^{* *}$ & $-0.572 * *$ & $-0.463^{*}$ \\
\hline
\end{tabular}

\#me $100 \mathrm{~g}^{-1}$ soil, *is Significant at $\mathrm{p}<0.05, * *$ is significant at $\mathrm{p}<0.01$, SDM: Shoot dry matter.

Table 7. Root dry mass (RDM), elemental concentrations $(\%)$ and miliequivalent (me) correlations $(\mathrm{p}<0.01$ and $\mathrm{p}<0.05)$

\begin{tabular}{|c|c|c|c|c|c|c|c|c|c|c|c|c|}
\hline & RDM & $(\mathrm{Ca} \%)$ & $(\mathrm{Mg} \%)$ & $(\mathrm{Na} \%)$ & $(\mathrm{K} \%)$ & $(\mathrm{Ca} / \mathrm{Na})$ & $(\mathrm{Mg} / \mathrm{Na})$ & $(\mathrm{K} / \mathrm{Na})$ & (Proline) & $(\mathrm{Ca} \#)$ & $(\mathrm{Mg} \#)$ & $(\mathrm{K} \#)$ \\
\hline$(\mathrm{Ca} \%)$ & $\begin{array}{l}0.073 \\
0.099\end{array}$ & & & & & & & & & & & \\
\hline$(\mathrm{Mg} \%)$ & $\begin{array}{l}0.099 \\
-0.500 * *\end{array}$ & $\begin{array}{l}0.926^{* *} \\
-0.547^{* *}\end{array}$ & $0.691 * *$ & & & & & & & & & \\
\hline $\begin{array}{l}\text { (Na\%) } \\
(\mathrm{K} \%)\end{array}$ & 0.196 & $0.973 * *$ & $0.968 * *$ & $-0.597 * *$ & & & & & & & & \\
\hline$(\mathrm{Ca} / \mathrm{Na})$ & $0.450 *$ & $0.876^{* *}$ & $0.920^{* *}$ & $-0.817^{* * *}$ & $0.887^{* *}$ & & & & & & & \\
\hline$(\mathrm{Mg} / \mathrm{Na})$ & $0.422 *$ & $0.777^{* *}$ & $0.922 * *$ & $-0.825^{* *}$ & $0.843^{* *}$ & $0.954 * *$ & & & & & & \\
\hline$(\mathrm{K} / \mathrm{Na})$ & $0.527^{* *}$ & $0.871^{* *}$ & $0.957 * *$ & $-0.793 * *$ & $0.922 * *$ & $0.974 * *$ & $0.981 * *$ & & & & & \\
\hline (Proline) & -0.243 & $-0.721^{* *}$ & $-0.791^{* *}$ & $-0.792 * *$ & $-0.744 * *$ & $\overline{0.861 * *}$ & $-0.848^{* * *}$ & $-0.844 * *$ & & & & \\
\hline (Came) & $0.716^{* *}$ & $0.592 * *$ & $0.586^{* *}$ & $-0.813^{* *}$ & $0.536^{* *}$ & $0.759 * *$ & $0.684^{* *}$ & $0.672 * *$ & $-0.789 * *$ & & & \\
\hline (Mgme) & $0.643^{* *}$ & $0.597 * *$ & $0.740 * *$ & $-0.868^{* *}$ & $0.650^{* *}$ & $0.854 * *$ & $0.887 * *$ & $0.835^{* *}$ & $-0.885 * *$ & $0.839^{* *}$ & & \\
\hline (Kme) & $0.742^{* *}$ & $0.724 * *$ & $0.803 * *$ & $-0.872^{* *}$ & $0.756^{* *}$ & $0.906 * *$ & $0.892 * *$ & $0.881^{* *}$ & $-0.899 * *$ & $0.877^{* *}$ & $0.972 * *$ & \\
\hline (Name) & 0.041 & $-0.786^{* *}$ & $-0.866^{* *}$ & $0.751^{* *}$ & $-0.849^{* *}$ & - & $-0.920^{* *}$ & $-0.926^{* *}$ & $0.824 * *$ & $-0.678^{* *}$ & $-0.882 * *$ & $-0.905 * *$ \\
\hline
\end{tabular}

\# me $100 \mathrm{~g}-{ }^{1}$ soil, $*$ is Significant at $\mathrm{p}<0.05, * *$ is significant at $\mathrm{p}<0.01, \mathrm{RDM}$ : Root dry matter. 
Table 8. SDM, proline and micronutrient correlations $(\mathrm{p}<0.01$ and $\mathrm{p}<0.05)$

\begin{tabular}{lccccc}
\hline & $(\mathrm{SDM})$ & (Proline) & $(\mathrm{B})$ & $(\mathrm{Zn})$ & $(\mathrm{Fe})$ \\
\hline (Proline) & -0.351 & & & & \\
$(\mathrm{~B})$ & -0.136 & $-0.607^{* *}$ & & & \\
$(\mathrm{Zn})$ & 0.314 & $-0.774^{* *}$ & $0.738^{* *}$ & & \\
$(\mathrm{Fe})$ & 0.112 & $-0.588^{* *}$ & $0.443^{*}$ & $0.738^{* *}$ & \\
$(\mathrm{Cu})$ & 0.046 & $0.738^{* *}$ & $0.865^{* *}$ & $0.880^{* *}$ & $0.720^{* *}$ \\
\hline
\end{tabular}

*is Significant at $\mathrm{p}<0.05, * *$ is significant at $\mathrm{p}<0.01$, RDM: Root dry matter, B: Boron, Zn: Zinc, Fe: Iron.

Table 9. RDM, proline and micronutrient correlations $(\mathrm{p}<0.01$ and $\mathrm{p}<0.05)$

\begin{tabular}{lccccc}
\hline & $(\mathrm{RDM})$ & (Proline) & $(\mathrm{B})$ & $(\mathrm{Zn})$ & $(\mathrm{F})$ \\
\hline (Proline) & -0.243 & & & & \\
$(\mathrm{~B})$ & 0.171 & $-0.911^{* *}$ & & & \\
$(\mathrm{Zn})$ & -0.073 & $-0.748^{* *}$ & $0.893^{* *}$ & & \\
$(\mathrm{Fe})$ & -0.310 & $0.691^{* *}$ & $-0.550^{* *}$ & -0.293 & \\
$(\mathrm{Cu})$ & -0.137 & $-0.808^{* *}$ & $0.905^{* *}$ & $0.905^{* *}$ & $-0.537 * *$ \\
\hline
\end{tabular}

*is significant at $\mathrm{p}<0.05, * *$ is significant at $\mathrm{p}<0.01, \mathrm{RDM}$ : Root dry matter, B: Boron, Zn: Zinc, Fe: Iron.

As seen in Tables 8-9, there was no correlation between the micronutrients and the root and shoot dry weights of wheat seedlings under saline conditions. Some micronutrients appeared to have a positive or negative correlation among them. The proline contents of the evaluated wheat seedlings had a strongly negative or moderately negative correlation with all micronutrient contents. Under the salinity stress, the $(\mathrm{Fe})$ contents (especially root samples have approximately two fold more $\mathrm{Fe}$ ) of plants increased as compared with the control groups, for example in the emmer wheat (Sheng et al., 2019) and rice (Oryza sativa) (Irakoze et al., 2019). While the (Fe) accumulation was observed in the line of AU5924 and the Bayraktar 2000, it is interesting to see that the (Fe) accumulation did not occur in salt-resistant line 5907. In light of these findings, it would not be wrong to conclude that the (Fe) status of the line AU5907 was associated with the salt tolerance. As with the value of proline, the slight increase in the $(\mathrm{Fe})$ content of stressed plants or an equal quantity of the (Fe) accumulation just like unstressed plants could be a sign of salt stress resistance in the present study.

\subsection{Conclusion}

In the current study, the responses against the salinity stress of certain selected wheat genotypes (two of them were extra salinity tolerant introgressed lines of Australian origin, and the other one was a well-adapted cultivar to the Central Anatolian conditions) were determined using the hydroponic system. The line AU5907 was found to be performing best among the examined genotypes. Parameters such as shoot dry mass, $(\mathrm{Na})$ rates of shoots, proline contents, and $(\mathrm{K} / \mathrm{Na})$ were employed on experimentally grown plants to find the best performing line. Although the results were closely related, the Nax loci introgressed lines were found to be better than the compared cultivar (the Bayraktar 2000), while line AU5907 was at the forefront. The ultimate goal of the study was to compare Nax-introgressed Australian wheat lines and well-adapted cultivar in terms of their performance to salt stress in a controlled environment and field conditions. Consequently, locally well-adapted cultivars could be developed to cope with the salinity stress by enlarging their genetic background with extra tolerance loci, of which Naxl and Nax2 (in this case) had great potential for wheat improvement programs owing to their easy tracking nature via related molecular markers. Therefore, these could be easily integrated into any marker-assisted selection programs.

\section{Acknowledgments}

- This manuscript has been written from a part of the master thesis entitled "Determination of the stress responses and mineral compositions of different wheat genotypes under salt treatment" published in the Council of Higher Education (Turkey) with the number 409905. 
- Thank CSIRO for sending these wheat line seeds that have been used within the master thesis (409905) and within the scope of the TUBİTAK project (Grant no: TOVAG 214O072).

- This work was supported by Scientific and Technological Research Council of Turkey (TÜBİTAK) (Grant no: TOVAG 2140072).

\section{References}

Ami, K., Planchais, S., Cabassa, C., Guivarc'h, A., Very, A.A., Khelifi, M., Djebbar, R., AbrousBelbachir, O., \& Carol, P. (2020). Different proline responses of two Algerian durum wheat cultivars to in vitro salt stress. Acta Physiologiae Plantarum, 42(21), 1-16.

Bhaskara, G.B., Nguyen, T.T., \& Verslues, P.E. (2012). Unique drought resistance functions of the highly ABA-induced clade a protein phosphatase 2cs. Plant Physiol, 160(1), 379-395.

Cirillo, V., Masin, R., Maggio, A., \& Zanin, G. (2018). Crop-weed interactions in saline environments. European Journal of Agronomy, 99, 51-61.

Dugasa, M.T., Cao, F., Ibrahim, W., \& Wu, F. (2019). Differences in physiological and biochemical characteristics in response to single and combined drought and salinity stresses between wheat genotypes differing in salt tolerance. Physiologia Plantarum, 165(2), 134-143.

El-Hendawy, S.E., Hassan, W.M., Al-Suhaibani, N.A., Refay, Y., \& Abdella, K.A. (2017). Comparative performance of multivariable agro-physiological parameters for detecting salt tolerance of wheat cultivars under simulated saline field growing conditions. Front Plant Sci, 8(435), 1-15.

Ghosh, B., Ali, M.N., \& Gantait, S. (2016). The response of rice under salinity stress: A review update. Rice Research: Open Access, 4(2,) 1-8.

Hakki, E.E., Dograr, N., Pandey, A., Khan, M.K., Hamurcu, M., Kayis, S.A., Gezgin, S., Olmaz, F., \& Akkaya, M.S. (2014). Molecular and Elemental Characterization of Selected Turkish Durum Wheat Varieties. Notulae Botanicae, 42(2) 431-439.

Hamurcu, M., Demiral, T., Hakki, E.E., Turkmen Ö., Gezgin, S., \& Bell, R.W. (2015). Oxidative stress responses in watermelon (Citrullus lanatus) as influenced by boron toxicity and drought. Zemdirbyste, 102 (2), 209-216.

Irakoze, W., Vanpee, B., Rufyikiri, G., Dailly, H., Nijimbere, S., \& Lutts, S. (2019). Comparative effects of chloride and sulfate salinities on two contrasting rice cultivars (Oryza sativa L.) at the seedling stage. Journal of Plant Nutrition, 42(9), 1001-1015.

Isayenkov, S.V., \& Maathuis, F.J.M. (2019). Plant Salinity Stress: Many unanswered questions remain. Front Plant Sci, 10(8,), 1-11.

James, R.A., Blake, C., Byrt, C.S., \& Munns, R. (2011). Major genes for $\mathrm{Na}^{+}$exclusion, Naxl and Nax2 (wheat $H K T 1 ; 4$ and $H K T 1 ; 5$ ), decrease $\mathrm{Na}^{+}$accumulation in bread wheat leaves under saline and waterlogged conditions. J Exp Bot, 62(8), 2939-2947.

James, R.A., Blake, C., Zwart, A.B., Hare, R.A., Rathjen, A.J., \& Munns, R. (2012). Impact of ancestral wheat sodium exclusion genes Naxl and Nax2 on grain yield of durum wheat on saline soils. Functional Plant Biology, 39(7), 609-618.

James, R.A., Davenport, R.J., \& Munns, R. (2006). Physiological characterization of two genes for $\mathrm{Na}+$ exclusion in durum wheat, Naxl and Nax2. Plant Physiol, 142(4), 1537-1547.

Khan, A., Shafi, M., Bakht, J., Khan, M., \& Anwar, S. (2019). The response of wheat varieties to salinity stresses is ameliorated by seed priming. Pak J Bot, 51(6), 1969-1978.

Kim, J., Liu, Y., Zhang, X., Zhao, B., \& Childs, K.L. (2016). Analysis of salt-induced physiological and proline changes in 46 switchgrass (Panicum virgatum) lines indicates multiple response modes. Plant Physiol Bioch, 105, 203-212.

Kobayashi, Yamaji, N., Yamamoto, H., Okubo, K., Ueno, H., Costa, A., Tanio, K., \& Matsumura, H. ve ark. (2017). OsHKT1;5 mediates $\mathrm{Na}^{+}$exclusion in the vasculature to protect leaf blades and reproductive tissues from salt toxicity in rice. The Plant Journal, 91(4), 657-670.

Maathuis, F.J.M. (2009). Physiological functions of mineral macronutrients. Curr Opin Plant Biol, 12(3), 250-258.

Munns, R., \& James, R.A. (2003). Screening methods for salinity tolerance: a case study with tetraploid wheat. Plant and Soil, 253(1), 201-218. 
Munns, R., James, R.A., Xu, B., Athman, A., Conn, S.J., Jordans, C., Byrt, C.S., Hare, R.A., \& Tyerman, S.D. ve ark. (2012). Wheat grain yield on saline soils is improved by an ancestral $\mathrm{Na}^{+}$transporter gene. Nature Biotechnology 30(4), 360-364.

Naz, T., Javaid, A., Anwar-ul-Haq, M., Saqib, M., \& Shahid, M. (2018). Interaction of salinity and boron in wheat affects physiological attributes, growth and activity of antioxidant enzymes. Pakistan Journal of Agricultural Sciences, 55, 339-347.

Per, T.S., Khan, N.A., Reddy, P.S., Masood, A., Hasanuzzaman, M., Khan, M.I.R., \& Anjum, N.A. (2017). Approaches in modulating proline metabolism in plants for salt and drought stress tolerance: Phytohormones, mineral nutrients and transgenics. Plant Physiol Bioch, 115, 126140.

Rahnama, A., Munns, R., Poustini, K., \& Watt, M. (2011). A screening method to identify genetic variation in root growth response to a salinity gradient. $J$ Exp Bot, 62(1), 69-77.

Rattan, R.K. (2015). Mineral nutrition of plants. In: Rattan, R.K., Katyal, J.C., Dwivedi, B.S., Sarkar, A.K., Bhattacharyya, T., Tarafdar, J.C., Kukal, S.S. (eds) Soil science: an introduction. Indian Soc Soil Sci, New Delhi, pp. 499-539.

Shaaf, S., Bretani, G., Biswas, A., Fontana, I.M., \& Rossini, L. (2019). Genetics of barley tiller and leaf development. J Integr Plant Biol, 61(3), 226-256.

Sheng, H., Zeng, J., Liu, Y., Wang, X., Wang, Y., Kang, H., Fan, X., Sha, L., Zhang, H., \& Zhou, Y. (2019). Differential responses of two wheat varieties differing in salt tolerance to the combined stress of mn and salinity. Journal of Plant Growth Regulation, doi:10.1007/s00344019-10023-0.

Sienkiewicz-Cholewa, U., Sumisławska, J., Sacała, E., Dziągwa-Becker, M., \& Kieloch, R. (2018). Influence of silicon on spring wheat seedlings under salt stress. Acta Physiologiae Plantarum, 40(3), 54-62.

Silva-Ortega, C.O., Ochoa-Alfaro, A.E., Reyes-Aguero, J.A., Aguado-Santacruz, G.A., \& JimenezBremont, J.F. (2008). Salt stress increases the expression of the $p 5 c s$ gene and induces proline accumulation in cactus pear. Plant Physiology and Biochemistry, 46(1), 82-92.

Singh, A. (2010). Decision support for on-farm water management and long-term agricultural sustainability in a semi-arid region of India. Journal of Hydrology, 391(1), 63-76.

Tounsi, S., Feki, K., Hmidi, D., Masmoudi, K., \& Brini, F. (2017). Salt stress reveals differential physiological, biochemical and molecular responses in T. monococcum and T. durum wheat genotypes. Physiology and Molecular Biology of Plants, 23(3), (pp. 517-528).

Valipour, M. (2014). Drainage, waterlogging, and salinity. Archives of Agronomy and Soil Science 60(12), 1625-1640.

Van Bezouw, R., Janssen, E.M., Ashrafuzzaman, M., Ghahramanzadeh, R., Kilian, B., Graner, A., \& Visser, R. G. F. (2019). Shoot sodium exclusion in salt-stressed barley (Hordeum vulgare L.) is determined by allele-specific increased expression of HKT1;5. J Plant Physiol, 241, 153029.

Wang, J., Vanga, S.K., Saxena, R., Orsat, V., \& Raghavan, V. (2018). Effect of climate change on the yield of cereal crops: A Review. Climate, 6(2), 41-60.

Zörb, C., Geilfus, C.M., \& Dietz, K.J. (2019). Salinity and crop yield. Plant Biology 21, 31-38. 